Jumal Matematika dan Aplikasi
ISSN:2302-4224
Jo o u r n a l ho m e pa g e: https:/lejournal.unsrat.ac.id/index.php/decartesian

\title{
Application Of Vehicle Routing Problem Using Clarke And Wright Algorithm For Distribution Of White Sugar By "Toko Bersama Trader"
}

\author{
Rondo V. S. A. Morihito, Chriestie E. J. C. Montolalu', Benny Pinontoan1* \\ ${ }^{1}$ Mathematics Department -Faculty of Mathematics and Natural Sciences-University of Sam Ratulangi, Manado, Indonesia \\ Corresponding author: bpinto@yahoo.com
}

\begin{abstract}
A B S T R A C T
The problem which is often experienced in the delivery of goods from distributor to the destination is the delivery route which is not sufficient with the capacity of the vehicle. This matter is very important because it can affect the trust of the clients on the shippers in the distributor. This problem can be analyzed using Capacitated Vehicle Routing Problem (CVRP) with Clarke and Wright Algorithm. This research begins with determining the distance between all coordinates with Euclidean Distance, making the distance matrix between places to go. After that, the calculation CVRP using Clarke and Wright Algorithm is exected in this study, a calculate CVRP using Clarke and Wright algorithm can help of the computer. The study was conducted at 15 shop coordinates, the results obtained by 4 routes with total load $3750 \mathrm{~kg}$ and distance $29.8510 \mathrm{~km}$. Route of delivery the first route 1100 $\mathrm{kg}$ load and distance $11.5963 \mathrm{~km}$, second route $1000 \mathrm{~kg}$ load and distance $6.6493 \mathrm{~km}$, third route $1000 \mathrm{~kg}$ load and distance $2.7549 \mathrm{~km}$, and the fourth route $650 \mathrm{~kg}$ load and distance $8.8505 \mathrm{~km}$.
\end{abstract}

\author{
ARTICLE INFO \\ Received : July 17,2018 \\ Received in revised form : July 23, 2018 \\ Available online : July 30, 2018
}

Ke ywo r d s:

Distributor,

Vehicle Routing Problem,

Capacitated Vehicle Routing Problem,

Clarke and Wright Algorithm

\section{INTRODUCTION}

Distributor is an intermediary in distributing goods from factories to stores that need these goods without having to modify the goods. Distributors have the duty to purchase products from the manufacturer, clarify the product according to the type, size, and quality of each item and introduce the product to the consumer.

Things that do not need to think about the problems of the product and marketing because it is already the responsibility of the manufacturer or factory that produces goods. The thing that often happens in distributing is when delivery of goods in choosing a route that is fast and in accordance with the route. Route determination in the delivery of goods is important. In this case is a route that is not in accordance with the cargo of goods that can make delivery of goods in one shop to be less even more than one store that is not in accordance with the demand.
Route determination problems and cargo loads can be solved using the Capacitated Vehicle Routing Problem (CVRP) method. Capacitated Vehicle Routing Problem is a method of finding the best and fastest travel route by maximizing the load of goods in the vehicle. The problem of Capacitated Vehicle Routing Problem has been supporting algorithm in determining route like Clarke and Wright algorithm, Sweep algorithm, Fisher and Jaikumar algorithm and the other.

Based on the above description, this study discusses the problem solving of Capacitated Vehicle Routing Problem using Clarke and Wright algorithm by taking case study in "Toko Bersama Trader" and will make Decision Support System in determining the distribution of goods. This research begins by determining each distance from shipping stores by using Euclidean Distance. In addition to using the Capacitated Vehicle Routing Problem method, it uses Clarke and Wright algorithm to determine the delivery 
route. The result from Euclidean Distance will be calculated to get the savings list from the savings list result will determined the delivery route. This research also utilizes help of computer.

\section{GRAPH THEORY}

Graph $G$ is defined as a pair $(V, E)$, written with the notation $G=(V, E)$, written with the notation $G=$ $(V, E)$, which in this case $V$ is the set of non-empty node - the node (vertices or nodes ) and $\mathrm{E}$ is the set sides (edges or arcs) connecting a pair of vertices. Graphs are usually represented by diagrams in which the vertices are points. An edge $x y$ is shown as a line from (the point representing) $x$ to (the point representing) $y$. To distinguish the vertices from other points in the plane, they are often drawn as small circles or large dots.

Two vertices on non-directed graph $G$ is said to be neighbors if the two are connected directly to a side. In other words, $u$ adjacent to $v$ if $(u, v)$ is an edge in a graph degree of a node in non-trending graph is the number of side by side with that node [1].

Euclidean distance is the calculation of 2-point distance in Euclidean space. Euclidean space was introduced by Euclid, Greek mathematician about 300 years before the general era to study the relationship between angle and distance. Euclidean is related with Phytagoras theorem [2] :

$$
d=\sqrt{\left(x_{1}-x_{2}\right)^{2}+\left(y_{1}-y_{2}\right)^{2}}
$$

Even from the above formula we can be implemented into :

$$
\mathrm{d}=\sqrt{\left(\text { Long }_{1}-\text { Long }_{2}\right)^{2}+\left(\text { Lat }_{1}-\text { Lat }_{2}\right)^{2}}
$$

\section{VEHICLE ROUTING PROBLEM}

The problem of finding optimal routes for groups of vehicles, the Vehicle Routing Problem (VRP), belongs to the class of NP-hard combinatorial problems. The fundamental objectives are to find the minimal number of vehicle, the minimal travel time or the minimal costs of travelled routes. In practice the basic formulation of the Vehicle Routing Problem (VRP) problem is augmented by constraints such as e.g. vehicle capacity or time interval in which each customer has to be served, trevealling the Capacitated Vehicle Routing Problem (CVRP) and the Vehicle Routing Problem (VRP) with Time Windows (VRPTW) respectly [3].

\subsection{Capacitated Vehicle Routing Problem}

The Capacitated Vehicle Routing Problem (CVRP) is one of the fundamental problems in the combinatorial optimization with a number of pratical application in transportation, distribution and logistics. The aim of CVRP is to find a set of minimum total cost routes for fleet of capacitated vehicles based at single depot [4].

The capacitited vehicle routing problem (CVRP) can be represented as a weighted directed graph $G=(V, A)$ where $V=\left\{v_{o}, v_{1}, v_{2}, \ldots, v_{n}\right\}$ represents the set of the vertices and $A=\{(v i, v j),: i \neq j\}$ represents the set of arcs. The vertex $V_{\mathrm{o}}$ represents the depot and the others represent the clients. To each $\operatorname{arc}\left(V_{i}, V_{j}\right)$ a non negative value $d_{i j}$ is associated. This value corresponds to the distance berween the vertex $v_{i}$ and the vertex $v_{j}$ in terms of cost or time between the two vertices. A demand $q_{i}$ and time service $\delta_{i}\left(q_{o}=0, \delta_{o}=0\right)$ are associated with each client (vertex) $v_{i}$. In this case, the objective is to minimize the total cost of routing and at the same time vehicle, all the vehicle paths or routes start and end at the depot, the total demand of clients of each path or routes should not exceed the capacity each vehicle. The number of vehicles is supposed to be illimited ; it is calculated during the contruction of the routes of vehicle.

\subsection{Clarke and Wright Algorithm}

The Clarke and Wright algorithm is the most popular heuristic algorithm for the Vehicle Routing Problem. The algorithm calculate all the savings $S_{i j}$ between customers $i$ and $j$. Assuming that $c_{i o}$ is the cost of travelling from customer $i$ to $j$. The following is a description of Clarke and Wright algorithm to solve CVRP:

- $\quad$ Step 1 : Compute the savings $S_{i j}=c_{i o}+c_{o j}-c_{i j}$ for $i, j=1, \ldots, n$ and $i \neq j$ Rank the savings $S_{i j}$ and list them in descending order.

- Step 2 : Create the "savings list" process the savings list beginning with the top most entry in the list (the largest $S_{i j}$ ). For the savings under consideration $\left(S_{i j}\right)$, include link $(i, j)$ in a route if no route constraints will be violated through the inclusion of $(i, j)$. The following three cases need to be considered.

- Case 1 : If neither $i$ nor $j$ have already been assigned to a route, then a new route is initiated including both $i$ and $j$.

- Case 2 : If exactly one of the two points ( $i$ or $j$ ) has already been included in an existing route and that point is not interior to that route (a point is interior to a route if it is not adjacent to the depot in the order of traversal of point), then the link $(i, j)$ is added to that same route. If the point is interior and not violating the capacity then add $(i, j)$ to the same route. If it's violating the capacity make a new route with the point (costomer) $i$.

- Case 3 : If both $i$ and $j$ have already been included in two different existing routes and neither point is interior to its route, then the two routes are merged by connecting $i$ and $j$. If they are interior then the merge cannot be done.

- Step 3 : If the savings list $S_{i j}$ has not been exhausted, return to step 2, processing the next entry in the list; otherwise, stop [6]. 


\section{RESEARCH METHODOLOGY}

\subsection{Data Analysis}

The data to be analyzed is the data of the goods delivery route from "Toko Bersama Trader" in manado city. The data taken is white sugar delivery data with stores that often order. Each order of at least 1 sack, 1 sack weights $50 \mathrm{Kg}$. Vehicle used car mitsubishi colt L300 box, which can accommodate $1100 \mathrm{Kg}$ load. 15 custemoers are to be served from depot at location (124.846598, 1.483817).

\subsection{System Requirement Analysis}

In implementing the input data into the system, the system requires the processing to be able to manage the input data into expected results with the help of computer.

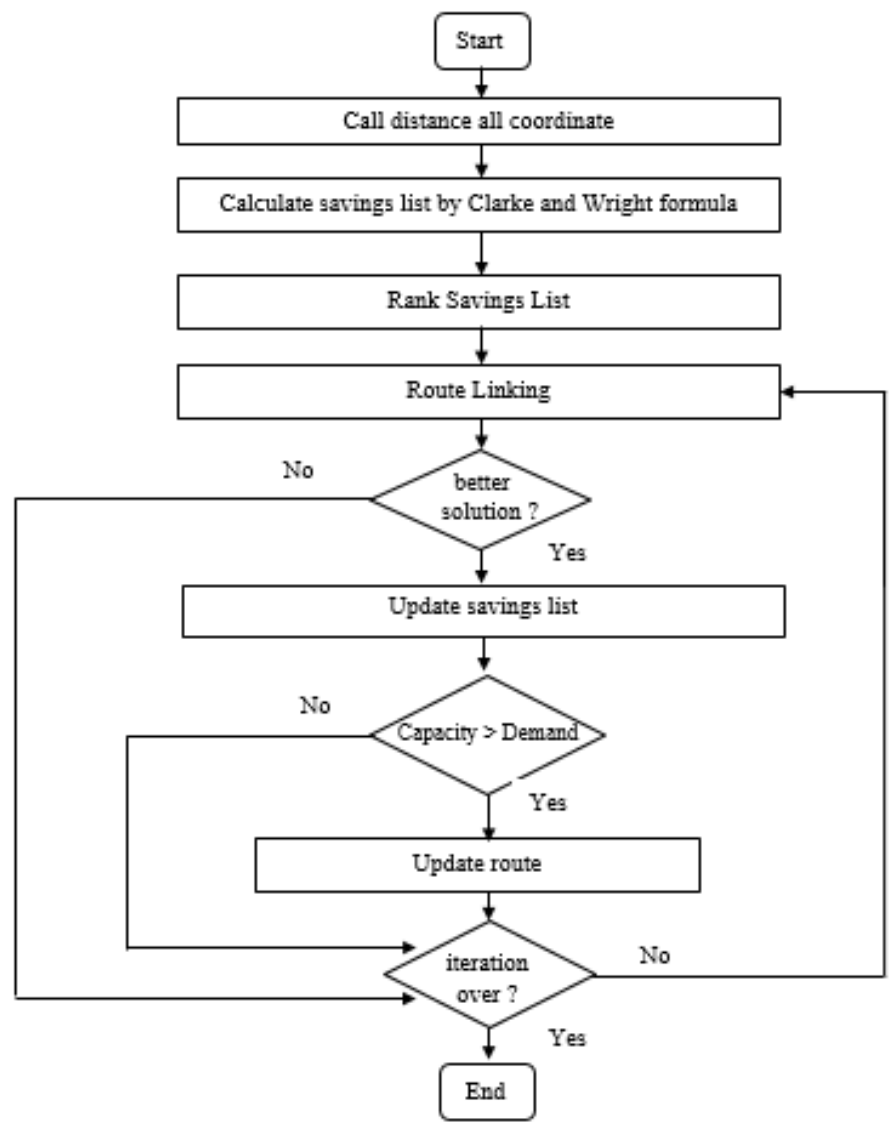

Figure 1. Chart Clarke and Wright Algorithm.

\section{RESULT AND DISCUSSION}

In this research for search delivery route of goods on "Toko Bersama Trader". In this case there are 16 store coordinate longitude and latitude, 15 store demand, and maximum box capacity of car which will be searched for the nearest route by maximizing box car capacity. Data coordinate and demand can be seen in the table 1.

Data in table 1 for data 1 is depot coordinate latitude and longitude and data 2 to 16 is store coordinate latitude and langitude.
Table 1. Data Coordinate and Demand.

\begin{tabular}{|l|c|c|c|c|}
\cline { 2 - 5 } \multicolumn{1}{l|}{} & \multicolumn{1}{c|}{ Name Store } & Longitude & Latitude & $\begin{array}{c}\text { Demand } \\
(\mathrm{Kg})\end{array}$ \\
\hline 1 & Depot & 124.846598 & 1.483817 & $\mathrm{O}$ \\
\hline 2 & Pelita Mas & 124.843571 & 1.496444 & 150 \\
\hline 3 & Tetap Jaya & 124.843565 & 1.495284 & 500 \\
\hline 4 & Damai Store & 124.844377 & 1.502776 & 100 \\
\hline 5 & Kemurahan Jaya & 124.842990 & 1.496592 & 500 \\
\hline 6 & Minahasa Indah & 124.842440 & 1.494629 & 500 \\
\hline 7 & Tedi Jaya & 124.836636 & 1.477913 & 150 \\
\hline 8 & Fendy Jaya Cell & 124.836827 & 1.482319 & 100 \\
\hline 9 & Surya Store & 124.836880 & 1.475056 & 100 \\
\hline 10 & Kurnia Store & 124.822009 & 1.459485 & 50 \\
\hline 11 & Desi Store & 124.839365 & 1.455563 & 500 \\
\hline 12 & Frivat & 124.839190 & 1.455364 & 250 \\
\hline 13 & Alam Raya & 124.838960 & 1.455987 & 500 \\
\hline 14 & Felin Store & 124.861026 & 1.484950 & 150 \\
\hline 15 & Irwan Store & 124.860946 & 1.484822 & 150 \\
\hline 16 & Kios Wangko & 124.859893 & 1.485687 & 50 \\
\hline
\end{tabular}

Maximum load box car is $1100 \mathrm{~kg}$. The first step is to find the distance between the coordinate latitude and longitude points using the euclidean distance. Once obtained distance is searched savings matrix from distance, for make savings matrix using Clarke and Wright algorithm formulation. Then rank savings list the biggest value until smallest value from savings matrix after that make route linking from savings list.

\subsection{Searching Distance Using Euclidean Distance Process}

For search the distance each coordinate, using euclidean distance formulation (2) to search the distance from two coordinate. Thus obtained :

$$
\begin{aligned}
d_{1,2} & =\sqrt{(124.846598-124.843571)^{2}+(1.483817-1.496444)^{2}} \\
& =\sqrt{(0.003027)^{2}+(-0.012627)^{2}} \\
& =\sqrt{0.000009162729+0.0001594411} \\
& =\sqrt{0.0001686038} \\
& =0.01298475
\end{aligned}
$$

The result of distance calculation from euclidean distance is still in decimal degree unit (according to longitude and latitude used) so it needs multiplied by 1 degree of earth ( 1 degree of earth = 111.319 Km).

$$
0.01298475 \times 111.319=1.4454 \mathrm{~km}
$$

For the other, calculate like that using equation (2) and multiplied by 1 degree of earth The results calculations of equation then the result distance matrix in table 1 , can be seen in the table 2 
Table 2. Distance Matrix Result

\begin{tabular}{|c|c|c|c|c|c|c|c|c|c|c|c|c|c|c|c|c|}
\hline & 1 & 2 & 3 & 4 & 5 & 6 & 7 & 8 & 9 & 10 & 11 & 12 & 13 & 14 & 15 & 16 \\
\hline 1 & 0 & 1.4454 & 1.3204 & 2.125 & 1.4778 & 1.2896 & 1.2891 & 1.1004 & 2.9814 & 3.8509 & 3.2467 & 3.2730 & 3.2127 & 1.6111 & 1.6012 & 1.4946 \\
\hline 2 & 1.4454 & 0 & 0.1291 & 0.7106 & 0.0667 & 0.2381 & 2.2026 & 1.7425 & 4.0138 & 4.7633 & 4.5750 & 4.5990 & 4.5329 & 2.3266 & 2.3270 & 2.1761 \\
\hline 3 & 1.3204 & 0.1291 & 0 & 0.8389 & 0.1591 & 0.1449 & 2.0819 & 1.6266 & 3.8952 & 4.6519 & 4.4465 & 4.4706 & 4.4046 & 2.2587 & 2.2584 & 2.1084 \\
\hline 4 & 2.125 & 0.7106 & 0.8389 & 0 & 0.7055 & 0.9322 & 2.8988 & 2.4275 & 4.7013 & 5.4245 & 5.2854 & 5.3095 & 5.2434 & 2.7153 & 2.7197 & 2.5695 \\
\hline 5 & 1.4778 & 0.0667 & 0.1591 & 0.7055 & 0 & 0.2269 & 2.1964 & 1.7307 & 4.0041 & 4.7454 & 4.5852 & 4.6090 & 4.5424 & 2.3898 & 2.3901 & 2.2393 \\
\hline 6 & 1.2896 & 0.2381 & 0.1449 & 0.9322 & 0.2269 & 0 & 1.9698 & 1.5061 & 3.7787 & 4.5254 & 4.3624 & 4.3860 & 4.3191 & 2.3328 & 2.3315 & 2.1831 \\
\hline 7 & 1.2891 & 2.2026 & 2.0819 & 2.8988 & 2.1964 & 1.9698 & 0 & 0.4909 & 1.8164 & 2.6191 & 2.5065 & 2.5262 & 2.4545 & 2.8259 & 2.8134 & 2.7298 \\
\hline 8 & 1.1004 & 1.7425 & 1.6266 & 2.4275 & 1.7307 & 1.5061 & 0.4909 & 0 & 2.2740 & 3.0303 & 2.9919 & 3.0122 & 2.9409 & 2.7098 & 2.6994 & 2.5950 \\
\hline 9 & 2.9814 & 4.0138 & 3.8952 & 4.7013 & 4.0041 & 3.7787 & 1.8164 & 2.274 & 0 & 0.9249 & 1.4044 & 1.4029 & 1.3399 & 4.2676 & 4.2523 & 4.2122 \\
\hline 10 & 3.8509 & 4.7633 & 4.6519 & 5.4245 & 4.7454 & 4.5254 & 2.6191 & 3.0303 & 0.9249 & 0 & 1.9808 & 1.9669 & 1.9268 & 5.1867 & 5.1714 & 5.1278 \\
\hline 11 & 3.2467 & 4.5750 & 4.4465 & 5.2854 & 4.5852 & 4.3628 & 2.5065 & 2.9919 & 1.4044 & 1.9808 & 0 & 0.0295 & 0.0653 & 4.0641 & 4.0473 & 4.0581 \\
\hline 12 & 3.2730 & 4.5990 & 4.4706 & 5.3095 & 4.6090 & 4.3860 & 2.5262 & 3.0122 & 1.4029 & 1.9669 & 0.0295 & 0 & 0.0739 & 4.0935 & 4.0767 & 4.0873 \\
\hline 13 & 3.2127 & 4.5329 & 4.4046 & 5.2434 & 4.5424 & 4.3191 & 2.4545 & 2.9409 & 1.3399 & 1.9268 & 0.0653 & 0.0739 & 0 & 4.0533 & 4.0366 & 4.045 \\
\hline 14 & 1.6111 & 2.3266 & 2.2587 & 2.7153 & 2.3898 & 2.3328 & 2.8259 & 2.7098 & 4.2676 & 5.1867 & 4.0641 & 4.0935 & 4.0533 & 0 & 0.0168 & 0.1505 \\
\hline 15 & 1.6012 & 2.3270 & 2.2584 & 2.7197 & 2.3901 & 2.3315 & 2.8134 & 2.6994 & 4.2523 & 5.1714 & 4.0473 & 4.0767 & 4.0366 & 0.0168 & 0 & 0.1517 \\
\hline 16 & 1.4946 & 2.1761 & 2.1084 & 2.5695 & 2.2393 & 2.1831 & 2.7298 & 2.5950 & 4.2122 & 5.1278 & 4.0581 & 4.0873 & 4.0450 & 0.1505 & 0.1517 & 0 \\
\hline
\end{tabular}

Table 3. Savings Matrix Result

\begin{tabular}{|c|c|c|c|c|c|c|c|c|c|c|c|c|c|c|c|c|}
\hline & 1 & 2 & 3 & 4 & 5 & 6 & 7 & 8 & 9 & 10 & 11 & 12 & 13 & 14 & 15 & 16 \\
\hline 1 & 0 & 0 & 0 & 0 & 0 & 0 & 0 & 0 & 0 & 0 & 0 & 0 & 0 & 0 & 0 & 0 \\
\hline 2 & & 0 & 2.6367 & 2.8598 & 2.8565 & 2.4969 & 0.5319 & 0.8033 & 0.4130 & 0.5330 & 0.1171 & 0.1194 & 0.1252 & 0.7299 & 0.7196 & 0.7639 \\
\hline 3 & & & 0 & 2.6065 & 2.6391 & 2.4651 & 0.5276 & 0.7942 & 0.4066 & 0.5194 & 0.1206 & 0.1228 & 0.1285 & 0.6728 & 0.6632 & 0.7066 \\
\hline 4 & & & & 0 & 2.8973 & 2.4824 & 0.5153 & 0.7979 & 0.4051 & 0.5514 & 0.0863 & 0.0885 & 0.0943 & 1.0208 & 1.0065 & 1.0501 \\
\hline 5 & & & & & 0 & 2.5405 & 0.5705 & 0.8475 & 0.4551 & 0.5833 & 0.1393 & 0.1418 & 0.1481 & 0.6991 & 0.6889 & 0.7331 \\
\hline 6 & & & & & & 0 & 0.6089 & 0.8839 & 0.4923 & 0.6151 & 0.1735 & 0.1766 & 0.1832 & 0.5679 & 0.5593 & 0.6011 \\
\hline 7 & & & & & & & 0 & 1.8986 & 2.4541 & 2.5209 & 2.0293 & 2.0359 & 2.0473 & 0.0743 & 0.0769 & 0.0539 \\
\hline 8 & & & & & & & & 0 & 1.8078 & 1.9210 & 1.3552 & 1.3612 & 1.3722 & 0.0017 & 0.0022 & 0 \\
\hline 9 & & & & & & & & & 0 & 5.9074 & 4.8237 & 4.8515 & 4.8542 & 0.3249 & 0.3303 & 0.2638 \\
\hline 10 & & & & & & & & & & 0 & 5.1168 & 5.157 & 5.1368 & 0.2753 & 0.2807 & 0.2177 \\
\hline 11 & & & & & & & & & & & 0 & 6.4902 & 6.3941 & 0.7937 & 0.8006 & 0.6832 \\
\hline 12 & & & & & & & & & & & & 0 & 6.4118 & 0.7906 & 0.7975 & 0.6803 \\
\hline 13 & & & & & & & & & & & & & 0 & 0.7705 & 0.7773 & 0.6623 \\
\hline 14 & & & & & & & & & & & & & & 0 & 3.1955 & 2.9552 \\
\hline 15 & & & & & & & & & & & & & & & 0 & 2.9441 \\
\hline 16 & & & & & & & & & & & & & & & & 0 \\
\hline
\end{tabular}

\subsection{Capacitated Vehicle Routing Prolem Using Clarke and Wright Algorithm Process}

In capacitated vehicle routing problem using clarke and wright savings algorithm process, the result that will be assimilated calculation of Clarke and Wright algorithm, the following is processing of Clarke and Wright algorithm :

a. Calculate The Savings List

To make matrix distance that's using equation (3) thus obtained:

$S_{23}=c_{12}+c_{13}-c_{23}=1.4454+1.3204-0.1291=2.6367$

$S_{24}=c_{12}+c_{14}-c_{24}=1.4454+2.1250-0.7106=2.8598$

$S_{25}=c_{12}+c_{15}-c_{25}=1.4454+1.4778-0.0667=2.8565$

$S_{26}=c_{12}+c_{16}-c_{26}=1.4454+1.2896-0.2381=2.4969$

For the other, calculate using equation (11) and value $S_{i j}$ is the same value $S_{j i}\left(S_{i j}=S_{j i}\right)$. The results calculations of equation then the result savings matrix can be seen in table 3 .

b. Rank Savings List and Route Linking

In rank savings list and route link, the top most entry in the list or largest $S_{i j}$ is consideration $\left(S_{i j}\right)$, include link $(i, j)$ in a route if no route constraints will be violated through the inclusion of $(i, j)$ from saving matrix in table 3 , sought the biggest value and obtained the following results. From iteration 1 to 4 result obtained corresponding to the constraint can be seen in table 4 .
Table 4. Savings List and Route Linking Result.

\begin{tabular}{|c|c|c|c|c|}
\hline Iteration & $\begin{array}{c}\text { Savings } \\
{[\mathrm{i}, \mathrm{j}]}\end{array}$ & Value & $\begin{array}{c}\text { Route } \\
\text { Linking }\end{array}$ & Demand \\
\hline \multirow{3}{*}{ Iteration I } & {$[11,12]$} & 6.4902 & $11-12$ & 750 \\
\cline { 2 - 5 } & {$[9,10]$} & 5.9074 & $9-10$ & 150 \\
\cline { 2 - 5 } & {$[14,16]$} & 2.9952 & $14-16$ & 200 \\
\hline \multirow{3}{*}{ Iteration II } & {$[4,5]$} & 2.8973 & $4-5$ & 600 \\
\cline { 2 - 5 } & {$[2,4]$} & 2.8598 & $2-4-5$ & 750 \\
\cline { 2 - 5 } & {$[7,8]$} & 1.8986 & $7-8$ & 250 \\
\hline Iteration III & {$[3,6]$} & 2.4651 & $3-6$ & 1000 \\
\hline Iteration IV & {$[13,15]$} & 0.7773 & $13-15$ & 650 \\
\hline
\end{tabular}

From the results of savings list and rank link got 4 route delivery with total load $3750 \mathrm{~kg}$ White Sugar and total distance $29.8510 \mathrm{~km}$. The results obtained from computer help and analysis are same result with data from "Toko Bersama Trader". Routes are formed is:

Table 5. Result of Delivery Route.

\begin{tabular}{|c|c|c|c|}
\hline Route & Store & $\begin{array}{c}\text { Load } \\
(\mathrm{kg})\end{array}$ & $\begin{array}{c}\text { Distance } \\
(\mathrm{km})\end{array}$ \\
\hline $\begin{array}{c}1-11- \\
12-9\end{array}$ & $\begin{array}{c}\text { Depot - Desi Store - } \\
\text { Frivat - Surya Store - } \\
-10-\end{array}$ & & \\
$14-16$ & Kurnia Store -Felin & 1100 & 11.5963 \\
-1 & $\begin{array}{c}\text { Store - Kios Wangko } \\
\text { - Depot }\end{array}$ & & \\
\hline $1-4-$ & $\begin{array}{c}\text { Depot - Pelita Mas - } \\
\text { Damai Store - }\end{array}$ & & \\
$5-2-$ & Kemurahan Jaya - \\
$7-8-$ & 1000 & 6.6493 \\
1 & $\begin{array}{c}\text { Tedi Jaya - Fendy - } \\
\text { Depot }\end{array}$ & \\
\hline
\end{tabular}




\begin{tabular}{|c|c|c|c|}
\hline $\begin{array}{c}1-3- \\
6-1\end{array}$ & $\begin{array}{c}\text { Depot - Tetap Jaya - } \\
\text { Minahasa Indah- } \\
\text { Depot }\end{array}$ & 1000 & 2.7549 \\
\hline $\begin{array}{c}1-13- \\
15-1\end{array}$ & $\begin{array}{c}\text { Depot - Felin Store - } \\
\text { Irwan Store - Depot }\end{array}$ & 650 & 8.8505 \\
\hline \multicolumn{2}{|c|}{ Total } & 3750 & 29.8510 \\
\hline
\end{tabular}

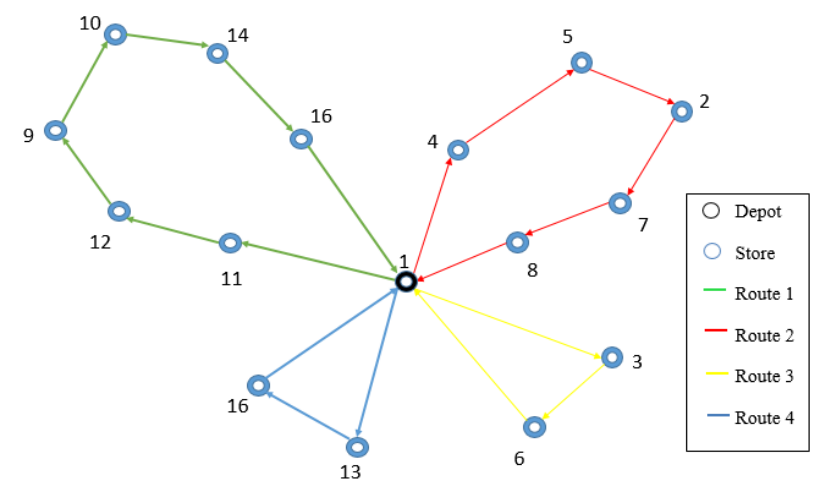

Figure 2. The Solution Capacitated Vehicle Routing Problem

Result from table 5 can make graf based on distance store for see the delivery routes of goods. The graf delivery route of goods can be seen in Figure 3 .
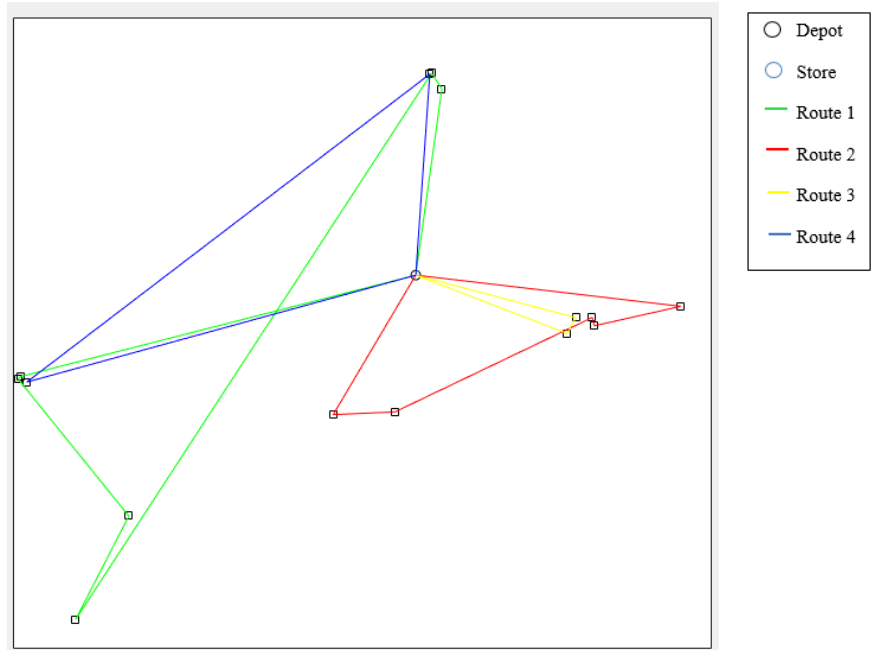

Figure 3. Delivery routes of goods based on distance store.

\section{CONCLUSION}

Capacitated Vehicle Routing Problem using Clarke and Wright algorithm can provide good solutions for search delivery routes of goods with see the biggest savings and capacity of vehicle. These results can be seen on route breaks with the help of computer.

\section{REFERENCES}

[1]. Murnir, R. 2014. Matematika Diskrit. Informatika. Bandung.

[2]. Setiawan, K., Sepriyadin., Santoso, I., and Buana, R. 2018. "Menghitung Rute Terpendek Mengunakan Algoritma A* Dengan Fungsi Euclidean Distances". Seminar Nasional Teknologi Informasi dan Komunikasi (SENTIKA). 70-79 ISSN : 2089-9815

[3]. Caric, T and Gold, H. 2008. Vehicle Routing Problem. I-Tech.

[4]. Borčinová, Z. 2017. Two Models Of The Capacitated Vehicle Routing Problem. Croation Operational Research Review. CRORR $8: 463$ 469.

[5]. Cacretta, L., Alaneen, M., and Abdul-Niby, M. 2013. An Improved Clarke and Wright Algorithm to Solve The Capacitated Vehicle Routing Problem. ETASR - Engineering, Technology and Applied Science Research. 3(2) : 413 - 415 .

\section{Rondo V.S.A Morihito(morihito01@gmail.com)}

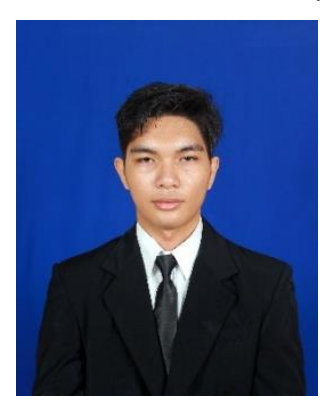
Born in Manado, North Sulawesi, Indonesia. He still studied bachelor degree in department of Mathematics, Faculty of Mathematics and Natural Sains at University of Sam Ratulangi Manado. In year 2018 was the last year he studied. This journal is the result of his published research.

Chriestie E.J.C Montolalu(chriestelly@yahoo.com)

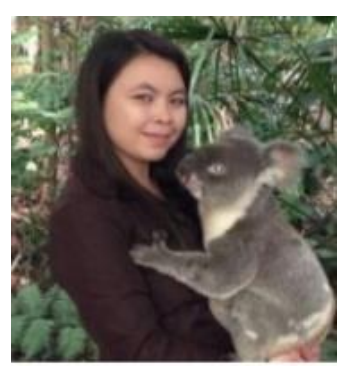
In 2007, her bachelor degree of Science at Unviersity Sam Ratulangi Manado. Master degree of Science at University of Queensland Australia in 2015. In 2008 until now she was lecture in department of Mathematics at University of Sam Ratulangi Manado.

Benny Pinontoan(bpinonto@yahoo.com)

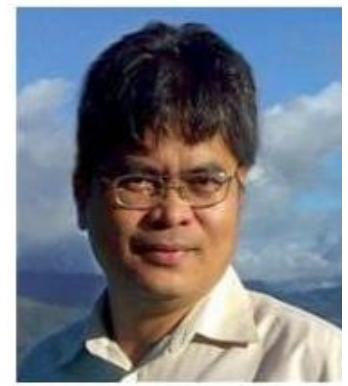

Born in Bitung, North Sulawesi, Indonesia, and lives in Manado. Completed his Bachelor degree in Technische Informatica at Faculteit Informatica Eindhoven, the Netherlands in 1993. In 2002 he completed his Doctoral degree in Mathematics at the school of Mathematics and Statistics, Carlethon University Ottwa Canada. In 1995 he was appointed lecture at Sam Ratulangi University (UNSRAT) and since 1 March 2006 became Professor of Mathematics at Faculty of Mathematics and Natural Sains, UNSRAT. 